\title{
ANALYTICAL TESTING OF THE INTERFERENCE STANDARD METHOD (IFS) FOR METALS IN WINES BY INDUCTIVELY COUPLED PLASMA MASS SPECTROMETRY
}

\author{
MÓNICA P. LATORRE ${ }^{a}$, RODRIGO A. VIDAL ${ }^{a}$, ELIZABETH GONZÁLEZ ${ }^{b}$, \\ ROSARIO CASTILLO ${ }^{a}$ CARLOS PEÑNA-FARFAL ${ }^{a}$, LEONARDO D. BENNUN" AND JOSÉ Y. NEIRA ${ }^{a *}$
}

\author{
${ }^{a}$ Departament of Instrumental Analysis, Faculty of Pharmacy, University of Concepcion, PO BOX 237, 4070043-Concepcion, Chile. \\ ${ }^{b}$ Faculty of Science, Catholic University of Santisima Concepcion, 4090541-Concepcion, Chile. \\ ${ }^{c}$ Departament of Physical, Faculty of Physical Sciences and Mathematics, University of Concepcion, Concepcion, Chile.
}

\begin{abstract}
An analytical testing study of interference standard method (IFS) for metals in wines with low and high residual sugar by inductively coupled plasma mass spectrometry (ICP-MS) was evaluated. Selection of IFS probes was based on the ions formed in the argon plasma, such as natural ${ }^{38} \mathrm{Ar}^{+}$or contaminant like ${ }^{83} \mathrm{Kr}^{+}$or also ions provided from the matrix sample (for instance, ${ }^{13} \mathrm{C}^{+}$). The analytical signal was obtained from ratio between the original signals of the analyte and those of the IFS probe species. The accuracy was confirmed using a $t$-test statistic for comparison between the concentrations obtained by Flame Atomic Absorption Spectrometry (FAAS) and ICP-MS. In a first study, the IFS effect was analyzed by comparing the correlation coefficients obtained with or without dividing the analytical signal by the IFS. Using the ${ }^{83} \mathrm{Kr}^{+}$IFS probe provide always better results in the determination of $\mathrm{Fe}$, Mn and $\mathrm{Zn}$ compared to ${ }^{13} \mathrm{C}^{+}$and ${ }^{38} \mathrm{Ar}^{+}$.
\end{abstract}

Keywords: IFS, isobaric interferences, mass spectrometry, wine analysis

\section{INTRODUCTION}

The determination of the major, minor, trace and ultra-trace metallic elements in wines are important as those may have effects on the organoleptic properties and usually the concentration levels are routinely monitored throughout all stages of wine production [1]. Normally wines from Europe, America, Africa or Asia, the major metallic elements found are $\mathrm{Na}, \mathrm{K}$ and $\mathrm{Mg}$ (at the $\mathrm{mg} \mathrm{L}^{-1}$ levels) and the minor are heavy metals (as $\mathrm{Fe}, \mathrm{Cu}, \mathrm{Zn}$, $\mathrm{Cd}, \mathrm{Pb}$, etc, all at the $\mu \mathrm{g} \mathrm{L}^{-1}$ levels) [2,3]. Usually, these metallic elements are determined by flame atomic absorption spectrometry (principally alkalines, $\mathrm{Fe}, \mathrm{Mn}, \mathrm{Zn}, \mathrm{Cu}$, etc.) or graphite furnace atomic absorption spectrometry (principally $\mathrm{Cd}, \mathrm{Pb}, \mathrm{As}, \mathrm{Co}, \mathrm{Ni}$, etc.). However, inductively-couple plasma mass spectrometry (ICP-MS) and inductively-couple plasma optical emission spectrometry (ICP-OES) are the techniques most extensively used to perform the elemental characterization of wines [4-6]. A critical evaluation and discussion of recent applications on atomic spectrometry methods for wines analysis has been reviewed [4]. Such works explores the multi-element capabilities of inductively coupled plasma-mass spectrometry with collision/ reaction cell technology (CCT-ICP-MS) for the simultaneous determination of both spectrally interfered and non-interfered nuclides in wine samples using a single set of experimental conditions and pinpoint the main advantages and drawbacks associated to this kind of analysis, highlighting the effect of interferences linked to sample matrix as well as the strategies available to mitigate them through sample pretreatment, sample dilution, sample digestion, etc. One of the most common interfering organic compound in wines is ethanol and residual sugar, whose typical concentrations are respectively between 9 to $18 \%(\mathrm{v} / \mathrm{v})$ and between 1 to $2 \%(\mathrm{p} / \mathrm{v})[5]$ and can change the signal of some analytical signals (for example, As and Se) [7-10]. Currently, ICP-MS is one of the most appropriate techniques for the determination of trace elements in wine [11]. However, the formation of molecular species in the plasma, such as $\mathrm{Ar}_{2}{ }^{+}, \mathrm{ArO}^{+}, \mathrm{ArN}^{+}, \mathrm{ArH}^{+}, \mathrm{MAr}^{+}, \mathrm{ArX}^{+}(\mathrm{M}$ is a metal and $\mathrm{X}$ a nonmetal) and other polyatomic species $\left(\mathrm{MO}^{+}, \mathrm{MOH}^{+}, \mathrm{XO}^{+}, \mathrm{XO}_{2}^{+}, \mathrm{XOH}^{+}\right)$ that cause isobaric interferences may worsen precision and accuracy [12-14]. Additionally, the formation of oxides can also deteriorate the sensitivity for elements such as $\mathrm{U}, \mathrm{Ba}$ and lanthanides $[15,16]$.

In general, the capacity for determining at ultra-trace level elements is inherent to ICP-MS, but it is well known that low resolution equipments with quadrupole mass analyzers are affected by spectral interferences [17]. Nowadays these interferences may be resolved using collision and reaction devices for destroying and filtering ion-molecular species $[4,18]$. Recently, a simple strategy based on the so-called interference standard method (IFS) has been proposed [19-23]. In this approach, an ion naturally formed in the argon plasma, such as $\mathrm{Ar}^{+}$or $\mathrm{ArO}^{+}$, is monitored and the ratio between the signals of the analyte and these species is used to improve accuracy. Similarly, also the use the specie ${ }^{129} \mathrm{Xe}^{+}$has been used as internal standard for the precise and accurate determination of several trace elements in different kinds of water samples by ICP-MS [24].

In this work, an analytical testing of the IFS method is evaluated and applied for wine with low and high residual sugar for three metallic elements (Fe, Mn and $\mathrm{Zn}$ ) by ICP-MS. These elements were selected as model in the application of IFS, but this last approach also could be used for other elements as $\mathrm{Cd}, \mathrm{Pb}, \mathrm{Hg}, \mathrm{As}, \mathrm{Co}, \mathrm{Ni}$, etc. The accuracy was confirmed using a $t$-test statistic for comparison between the concentrations obtained by FAAS and ICP-MS by using as IFS probe ${ }^{83} \mathrm{Kr}^{+},{ }^{13} \mathrm{C}^{+}$or ${ }^{38} \mathrm{Ar}^{+}$.

\section{EXPERIMENTAL}

\section{Reagents and materials}

Aqueous solutions were prepared with analytical grade chemicals and deionized water (resistivity higher than $18.2 \mathrm{M} \Omega \mathrm{cm}$ ) obtained from a Milli-Q water purification system (Millipore, Bedford, MA, USA). Nitric acid and ethanol (both from Merck, Darmstadt, Germany) were separately distilled in quartz sub-boiling still (Milestone, Sorisole, Italy). Fe, Mn and $\mathrm{Zn}$ calibration solutions were prepared by dilution from a $1000 \mathrm{mg} \mathrm{L}^{-1}$ stock solution (Titrisol concentrate, Merck, Darmstadt, Germany). For the synthetic wine sample the reagents were: Sucrose as sugar, Potassium, Calcium, Copper, Acetic Acid, Tartaric Acid (all Merck, Darmstadt, Germany). All standard solutions were

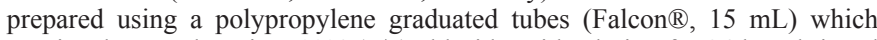
previously were kept in a $10 \%(\mathrm{v} / \mathrm{v})$ chloride acid solution for $24 \mathrm{~h}$ and rinsed with ultra-pure water.

Apparatus

An inductively coupled plasma mass spectrometer (ICP-MS, Varian 820-MS, Mulgrave, Australia) with quadrupole mass analyzer was used in all experiments. The sample introduction system was composed of concentric nebulizer and double path spray chamber (Scott type) made with perfluoroacetate (PFA) and an automatic sampler (SPS3, Varian). An additional gas flow controller (AGM-1, Varian) for adding oxygen $(99.99 \%$, White Martins, Sertãozinho-SP, Brazil) as auxiliary gas in the ICP was employed. Table 1 presents instrumental and operating conditions.

A flame atomic absorption spectrometry (Perkin Elmer model Analysis 300) equipped with a deuterium lamp background corrector. The instrument parameters for determination of $\mathrm{Fe}, \mathrm{Mn}$ and $\mathrm{Zn}$ were those recommended by the equipment manufacture [25]. Table 2 presents instrumental and operating conditions. 
Table 1. ICP-MS operating conditions.

\begin{tabular}{|c|c|c|}
\hline \multicolumn{3}{|c|}{ Operating conditions } \\
\hline Plasma gas flow rate & $\left(\mathrm{L} \mathrm{min}^{-1}\right)$ & 18 \\
\hline Auxiliary gas flow rate & $\left(\mathrm{L} \mathrm{min}^{-1}\right)$ & 1.80 \\
\hline Nebulizer gas flow rate & $\left(\mathrm{L} \mathrm{min}^{-1}\right)$ & 0.95 \\
\hline Sheath gas flow rate & $\left(\mathrm{L} \mathrm{min}^{-1}\right)$ & 0.12 \\
\hline Peristaltic pump rate & $(\mathrm{rpm})$ & 7 \\
\hline Sampling depth & $(\mathrm{mm})$ & 5.5 \\
\hline RF power & $(\mathrm{kW})$ & 1.4 \\
\hline Points per Peak & & 3 \\
\hline Scan per replicate & & 3 \\
\hline Scan per sample & & 3 \\
\hline Dwell time & $(\mathrm{ms})$ & 1 \\
\hline
\end{tabular}

Table 2. FAAS operating conditions.

\begin{tabular}{|c|c|c|c|c|}
\hline Instrumental parameters & & $\mathrm{Fe}$ & $\mathrm{Mn}$ & $\mathrm{Zn}$ \\
\hline Filament current & $\mathrm{mA}$ & 30 & 20 & 15 \\
\hline Wavelength & $\mathrm{nm}$ & 248.3 & 279.5 & 213.9 \\
\hline Oxidant flow (Air) & $\mathrm{L} \mathrm{min}^{-1}$ & 10.0 & 10.0 & 10.0 \\
\hline Fuel flow (Acetylene) & $\mathrm{L} \mathrm{min}^{-1}$ & 3.00 & 3.00 & 3.00 \\
\hline Slit & $\mathrm{nm}$ & 0.2 & 0.2 & 0.7 \\
\hline Background correction & & Yes & Yes & Yes \\
\hline
\end{tabular}

On the other hand, a conventional Carls Zeiss Refratometer (degrees Brix, $0-30^{\circ}$ Brix) was used to determine the high residual sugar.

\section{Sample wine and synthetic wine sample}

Different commercial wines with low and high residual sugar were provided by Viña de Neira (Guarilihue, Región del Bio Bio - Chile) and represent two types of grapes: red Pinot Noir (low residual sugar, 0,6\% w/v) and white Moscatel de Alejandria (high residual sugar, $14 \% \mathrm{w} / \mathrm{v}$ ), both from Chile. The ethanol concentration in wines is around $12 \%(\mathrm{v} / \mathrm{v})$.

Wine samples were analyzed without any step of sample digestion. The analysis by ICP-MS a simple $1: 10 \mathrm{v} / \mathrm{v}$ dilution with $0.14 \mathrm{~mol} \mathrm{~L}^{-1} \mathrm{HNO}_{3}$ was performed to reach an ethanol concentration around $1.2 \%(\mathrm{v} / \mathrm{v})$. For FAAS analysis, direct introduction was used. Also to ensure that concentrations of metals in wine were correct, we made a cross-calibration, for which FAAS determinations and standard addition methods were performed in two different laboratories, the first is the Instrumental Analysis at the Universidad de Concepcion (UdeC) and the second is the Environmental Chemistry at the Universidad Católica de la Santísima Concepcion (UCSC). The above mentioned analyses were tested because it is necessary to provide reliability in the determination of $\mathrm{Fe}, \mathrm{Mn}$ and $\mathrm{Zn}$, which were subsequently compared with the determination accuracy with IFS and ICP-MS. In addition, this strategy was used to check the accuracy of the analytical determinations by ICP-MS because no available a certified reference material wine. In general, all results obtaining from UdeC and UCSC showed not statically significant difference at a $95 \%$ confidence $(\mathrm{p}>0.05)$ [26].

In order to study the matrix effect in wine, a synthetic wine sample was prepared with ethanol $12 \% \mathrm{v} / \mathrm{v}$, residual sugar $0.6 \% \mathrm{w} / \mathrm{v}, \mathrm{Fe}+++0.96 \mathrm{mg} \mathrm{L}^{-1}$, $\mathrm{Mn}++1.4 \mathrm{mg} \mathrm{L}^{-1}, \mathrm{Zn}++0.40 \mathrm{mg} \mathrm{L}^{-1}, \mathrm{Cu}++0.15 \mathrm{mg} \mathrm{L}^{-1}$, Tartaric Acid $1.2 \mathrm{~g} \mathrm{~L}^{-1}$, Acetic Acid $0.50 \mathrm{~g} \mathrm{~L}^{-1}, \mathrm{~K} 980 \mathrm{mg} \mathrm{L}^{-1}$ and Ca $74 \mathrm{mg} \mathrm{L}^{-1}$. This concentration were employed because they are the levels normally found in wine.

\section{RESULTS AND DISCUSION}

The effect of sample matrix in wine with low and high residual sugar represent an important limitation to the application of inductively coupled plasma mass spectrometry determinations. Isobaric polyatomic ions are normally critical on accuracy specially in situations where the analyte is dependent on the determination of a single natural isotope (i.e. represents $100 \%$ of the elements) or elements with more than one isotope (i.e where the abundant species not representing $100 \%$ ), or when these major isotopes have a critical isobaric interference [20]. A case of critical isobaric interference is the determination by using ion isotope ${ }^{56} \mathrm{Fe}^{+}$(abundance ${ }^{56} \mathrm{Fe} 91.66 \%$ ) which is omnipresent with the interfering ion Ar overlap ${ }^{40} \mathrm{Ar}^{16} \mathrm{O}^{+}$and $\mathrm{O}$ overlap ${ }^{40} \mathrm{Ca}^{16} \mathrm{O}^{+}$. In this case, is advisable to use the ion isotope ${ }^{57} \mathrm{Fe}^{+}$even in low abundance (abundance ${ }^{57} \mathrm{Fe} 2.19 \%$ ). In relation to $\mathrm{Mn}$ and $\mathrm{Zn}$ determinations, no isobaric interferences are critical (Mn: principal isotope specie ${ }^{55} \mathrm{Mn}^{+}$ (abundance ${ }^{55} \mathrm{Mn} \mathrm{100 \% )} \mathrm{in} \mathrm{comparison} \mathrm{with} \mathrm{the} \mathrm{interfering} \mathrm{ion} \mathrm{Ar} \mathrm{overlap}$ ${ }^{40} \mathrm{Ar}^{14} \mathrm{~N}^{1} \mathrm{H}^{+}$and $\mathrm{Zn}$ : principal isotope specie ${ }^{64} \mathrm{Zn}^{+}$(abundance ${ }^{64} \mathrm{Mn} 48.89 \%$ ) in comparison with the interfering ion $\mathrm{O}$ overlap $\left.{ }^{48} \mathrm{Ti}^{16} \mathrm{O}^{+}\right)$. The use of IFS probe is not subject to a single species from Argon plasma (for example ion IFS probe as ${ }^{38} \mathrm{Ar}^{+}$or from a contaminant as $\left.{ }^{83} \mathrm{Kr}^{+}\right)$. Thus, is feasible to use the ion isotope ${ }^{13} \mathrm{C}^{+}$as IFS probe in wine samples because source of carbon (from ethanol and sugar) would supply a major natural abundance of $\operatorname{ion}^{13} \mathrm{C}^{+}$(natural abundance of ${ }^{13} \mathrm{C}$ is close to $1.09 \%$ ).

IFS strategy on repeatability and accuracy for Fe, Mn and $\mathrm{Zn}$ determination in wine

In relation to the critical isobaric interference of ion isotope ${ }^{56} \mathrm{Fe}^{+}$by ${ }^{40} \mathrm{Ar}^{16} \mathrm{O}^{+}$, in Fig. 1 is showed the effect of wine matrix when is used a sample wine and synthetic wine sample (both Fe $0.96 \mathrm{mg} \mathrm{L}^{-1}$ ) on repeatability $(\mathrm{n}=5)$ and accuracy when is recorded the original signal ( Fig. 1 a., isotope ${ }^{56} \mathrm{Fe}$ counts: for a wine sample and Fe standard) and the signal corrected by ${ }^{83} \mathrm{Kr}^{+}$as IFS probe (Fig. 1 b. by using IFS). In this conditions, when the original signal for wines is compared with the synthetic wine, a good repeatability is obtained (both analysis C.V. between 0.5 to $1.0 \%$ ), however, the calculated accuracy is poor (both samples, statistic parameter $\mathrm{p}<0.001$, indicating statically significant difference at a $95 \%$ confidence). On the other hand, in comparison with using ${ }^{83} \mathrm{Kr}^{+}$IFS as probe, a good accuracy is obtained (parameter $\mathrm{p}=$ 0.364 ), however a low repeatability was observed (both analysis between C.V. between 6 to $8 \%$ ). Regarding this latter, and in relation to $\mathrm{Mn}$ and $\mathrm{Zn}$ analysis in wine, the normal loss of repeatability and the gain in accuracy, also were observed, and further, these analyses are also consistent with those reported in previous works [19-21].
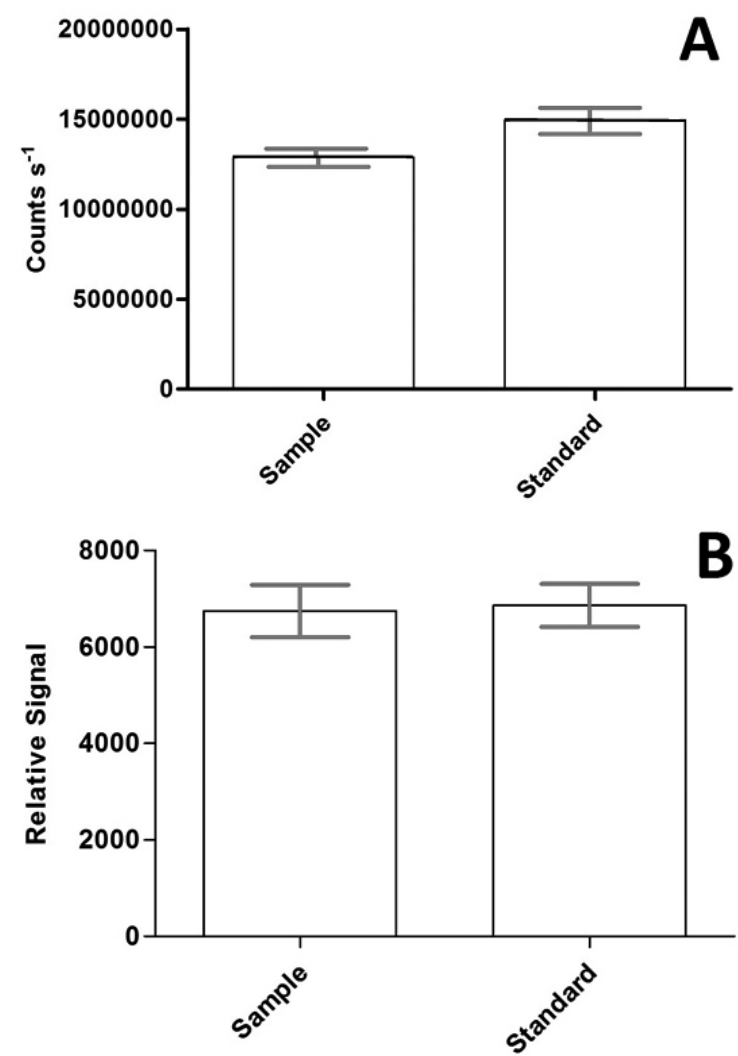

Fig. 1. Signal intensities for one wine sample (red Pinot Noir wine) and synthetic wine sample (both Fe $0.96 \mathrm{mg} \mathrm{L}^{-1}$ and replicas $\mathrm{n}=5$ ). A) original signal (counts) and B) analytical signal by using ${ }^{83} \mathrm{Kr}^{+}$IFS probe. 
Since, the results show that used of IFS compromises the sensitivity for species ${ }^{56} \mathrm{Fe}^{+},{ }^{57} \mathrm{Fe}^{+},{ }^{55} \mathrm{Mn}^{+}$and ${ }^{64} \mathrm{Zn}^{+}$determination by ICP-MS leading to poor detection limits respect when is used the original signal. As example, the Fig. 2 is presented the calibration curve for the ion isotope ${ }^{55} \mathrm{Mn}^{+}$(original signal) and by using IFS probe as: ${ }^{13} \mathrm{C}^{+},{ }^{38} \mathrm{Ar}^{+}$and ${ }^{83} \mathrm{Kr}^{+}$. Based on slope of linear regression equation a significative decreasing is always observed when any ISF is used (i.e. ${ }^{13} \mathrm{C}^{+},{ }^{38} \mathrm{Ar}^{+}$or $\left.{ }^{83} \mathrm{Kr}^{+}\right)$. In this condition, the best analytical signal (ratio between original signal/IFS interference) is by using the ${ }^{83} \mathrm{Kr}^{+}$IFS probe. In addition, based on correlation coefficient, also the best calibration curves are always obtained with this IFS probe. Regarding other metals (i.e. for ion based on ion isotope ${ }^{56} \mathrm{Fe}^{+}$and ${ }^{64} \mathrm{Zn}^{+}$), a similar trends were also observed. The Table 3 a summary for limits of detection (LOD) and limits of quantification (LOQ) is shown with and without IFS probes. The LOD and LOQ for all metals were calculated in according to report a previous work [20].

Table 3. Limits of detection (LOD) and quantification (LOQ) achieved for

$\mathrm{Fe}, \mathrm{Mn}$ and $\mathrm{Zn}$ by using different IFS probe $\left({ }^{13} \mathrm{C}^{+},{ }^{38} \mathrm{Ar}+\right.$ and $\left.{ }^{83} \mathrm{Kr}^{+}\right)$.

\begin{tabular}{|c|c|c|c|}
\hline Isotope & IFS condition & LOD, $\mu \mathrm{g} \mathrm{L}^{-1}$ & $\mathrm{LOQ}, \mu \mathrm{g} \mathrm{L}^{-1}$ \\
\hline \multirow{4}{*}{${ }^{56} \mathrm{Fe}$} & ${ }^{56} \mathrm{Fe}^{+}$ & 10 & 28 \\
\hline & ${ }^{56} \mathrm{Fe}^{+} /{ }^{13} \mathrm{C}^{+} / 13$ & 120 & 333 \\
\hline & ${ }^{56} \mathrm{Fe}^{+}{ }^{\beta 8} \mathrm{Ar}+$ & 97 & 311 \\
\hline & ${ }^{56} \mathrm{Fe}^{+} / 83 \mathrm{Kr}^{+} / 83$ & 28 & 55 \\
\hline \multirow{4}{*}{${ }^{55} \mathrm{Mn}$} & ${ }^{55} \mathrm{Mn}^{+}$ & 5 & 14 \\
\hline & ${ }^{55} \mathrm{Mn}^{+} /{ }^{13} \mathrm{C}^{+} / 13$ & 98 & 298 \\
\hline & ${ }^{55} \mathrm{Mn}^{+} / 38 \mathrm{Ar}+$ & 34 & 76 \\
\hline & ${ }^{55} \mathrm{Mn}^{+} / 83 \mathrm{Kr}^{+} / 83$ & 23 & 60 \\
\hline \multirow{4}{*}{${ }^{64} \mathrm{Zn}$} & ${ }^{64} \mathrm{Zn}^{+}$ & 8 & 22 \\
\hline & ${ }^{64} \mathrm{Zn}^{+} /{ }^{13} \mathrm{C}^{+} / 13$ & 160 & 424 \\
\hline & ${ }^{64} \mathrm{Zn}^{+/ 38} \mathrm{Ar}+$ & 95 & 276 \\
\hline & ${ }^{64} \mathrm{Zn}^{+} / 83 \mathrm{Kr}^{+} / 83$ & 17 & 54 \\
\hline
\end{tabular}

\section{Calibration curve IFS ${ }^{55} \mathrm{Mn}^{+} /{ }^{13} \mathrm{C}^{+}$}
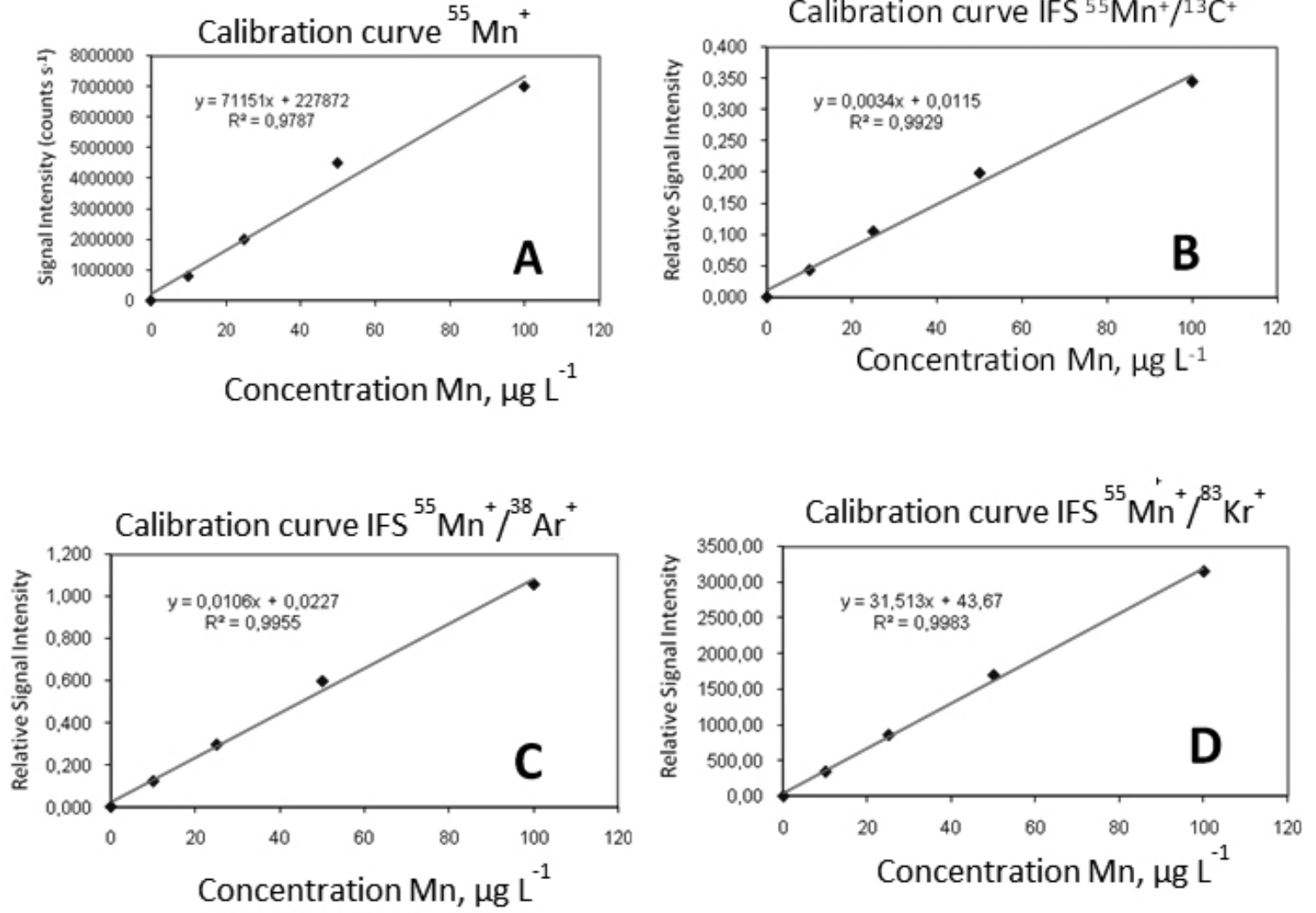

Fig. 2. Calibration Curves for Mn determination by using different IFS probes.

a) original signal; b) ${ }^{13} \mathrm{C}^{+}$IFS probe; c) ${ }^{38} \mathrm{Ar}^{+}$ISF probe; and d) ${ }^{83} \mathrm{Kr}^{+}$ISF probe.

Table 4 is presented the comparative study of the Fe, Mn and $\mathrm{Zn}$ determination obtained by using the original signal achieved by ICP-MS in comparison with those by FAAS (value accepted as true). This comparative study was performance in order the confirm the accuracy based a t-test statistic (parameter "p" to know if there is statistically significant differences). In this conditions, a critical loss of accuracy by ICP-MS is observed for Fe and Mn determination in wine with low residual sugar (all comparative determination $\mathrm{p}<0.05$ ). This loss of accuracy it is in relation to those isobaric interference mentioned above which probably is supply by wine sample matrix (for example critical isobaric interference: for isotope ${ }^{56} \mathrm{Fe}(91.72 \%)$ : Ar overlap ${ }^{40} \mathrm{Ar}^{16} \mathrm{O}^{+}$and $\mathrm{O}$ overlap ${ }^{40} \mathrm{Ca}^{16} \mathrm{O}^{+}$; for ${ }^{57} \mathrm{Fe}(2.2 \%)$ : Ar overlap ${ }^{40} \mathrm{Ar}^{16} \mathrm{OH}^{+}$and $\mathrm{O}$ overlap ${ }^{40} \mathrm{Ca}^{16} \mathrm{OH}^{+}$and for ${ }^{55} \mathrm{Mn}(100 \%)$ : Ar overlap ${ }^{40} \mathrm{Ar}^{14} \mathrm{NH}^{+}$and $\mathrm{O}$ overlap ${ }^{39} \mathrm{~K}^{16} \mathrm{O}^{+}$). Respect of Mn determination based on ion isotope ${ }^{55} \mathrm{Mn}^{+}$the critical loss accuracy by the ion specie ${ }^{39} \mathrm{~K}^{16} \mathrm{O}^{+}$it is in relation to the high concentration of potassium found normally in this wine $\left(\mathrm{K}>900 \mathrm{mg} \mathrm{L}^{-1}\right)$. Regarding $\mathrm{Zn}$ determination, no critical isobaric interference is observed by the principal interference on ICP-MS determination based on ${ }^{64} \mathrm{Zn}(48.6 \%)$ (titanium overlap ${ }^{48} \mathrm{Ti}^{16} \mathrm{O}^{+}$), because probably the supply of titanium concentration from this wine is low. Conversely, respect $\mathrm{Zn}$ determination based on ion isotope ${ }^{66} \mathrm{Zn}$ $(27.9 \%)$, which has been not a critical isobaric interference, a loss accuracy is observed $(\mathrm{p}<0.05)$. In relation the last, we have no justification for this not expected result. 
Table 4. Statistical comparison by using original signal for Fe, Mn and Zn determinations in wines with low residual sugar by ICP-MS and FAAS. Red Pinot Noir wine with residual sugar $0.6 \% \mathrm{w} / \mathrm{v}$

\begin{tabular}{|c|c|c|c|c|}
\hline \multirow[b]{2}{*}{ Isotope } & \multicolumn{2}{|c|}{ By ICP-MS } & \multicolumn{2}{|l|}{ By FAAS } \\
\hline & Linear equation & Concentration found ${ }^{*} \mathrm{mgL}^{-1}$ & Concentration found ${ }^{*} \mathrm{mgL}^{-1}$ & $\mathbf{p}^{* *}$ \\
\hline${ }^{56} \mathrm{Fe}$ & $\begin{array}{c}\mathrm{Y}=32307 \mathrm{X}+2633 \\
\mathrm{R}^{2}=0.9986\end{array}$ & $3.97 \pm 0.01$ & $0.961 \pm 0.020$ & 0.000 \\
\hline${ }^{57} \mathrm{Fe}$ & $\begin{array}{c}\mathrm{Y}=1624.4 \mathrm{X}-91.8 \\
\mathrm{R}^{2}=0.9979\end{array}$ & $1.97 \pm 0.04$ & $0.961 \pm 0.020$ & 0.000 \\
\hline${ }^{55} \mathrm{Mn}$ & $\begin{array}{c}\mathrm{Y}=68762 \mathrm{X}+77162 \\
\mathrm{R}^{2}=0.9950\end{array}$ & $2.041 \pm 0.05$ & $2.18 \pm 0.02$ & 0.010 \\
\hline${ }^{64} \mathrm{Zn}$ & $\begin{array}{c}\mathrm{Y}=8180.1 \mathrm{X}+844.8 \\
\mathrm{R}^{2}=0.9993\end{array}$ & $0.267 \pm 0.017$ & $0.284 \pm 0.003$ & 0.163 \\
\hline${ }^{66} \mathrm{Zn}$ & $\begin{array}{c}\mathrm{Y}=4937.5 \mathrm{X}+009.6 \\
\mathrm{R}^{2}=0.9996\end{array}$ & $0.378 \pm 0.026$ & $0.284 \pm 0.003$ & 0.003 \\
\hline
\end{tabular}

* The values reported are the average and \pm is the mean standard deviation, $\mathrm{n}=3$.

** Statistical parameter, $p>0.05$ indicates no statistically significant difference at $95 \%$ confidence.

Tables 5 and 6 show the comparative results (accuracy) regarding the use of ${ }^{83} \mathrm{Kr}^{+}$IFS probe in Fe, Mn and $\mathrm{Zn}$ determinations by ICP-MS in comparison with those obtained by FAAS in wines with low and high residual sugar, respectively. The accuracy was newly confirmed using a t-test statistic for comparison between the concentrations obtained by FAAS and ICP-MS. Based on the best result of statistical parameter "p", no statistically significant differences (always statistic parameter $\mathrm{p}>0,05$ ) were observed between values obtained by FAAS and ICP-MS using the ${ }^{83} \mathrm{Kr}^{+}$IFS probe for ${ }^{56} \mathrm{Fe}^{+},{ }^{57} \mathrm{Fe}^{+},{ }^{55} \mathrm{Mn}^{+},{ }^{64} \mathrm{Zn}^{+}$and ${ }^{6} \mathrm{Zn}^{+}$in wine with low or high residual sugar. Respect this last results it is consistent with previous work for the determination of sulfur, Mn and Fe in foods [21] and also for sulfur in biodiesel [22].

Table 5. Statistical comparison by using ${ }^{83} \mathrm{Kr}^{+}$IFS probe for Fe, Mn and $\mathrm{Zn}$ determinations in wines with low residual sugar by ICP-MS and FAAS. Red Pinot Noir wine with residual sugar $0.6 \% \mathrm{w} / \mathrm{v}$.

\begin{tabular}{|c|c|c|c|c|}
\hline \multirow[b]{2}{*}{ Isotope } & \multicolumn{2}{|c|}{ By ICP-MS IFS ${ }^{83} \mathbf{K r}^{+}$} & \multicolumn{2}{|l|}{ By FAAS } \\
\hline & Linear equation & Concentration found ${ }^{*} \mathrm{mgL}^{-1}$ & Concentration found* $\mathbf{m g L}^{-1}$ & $\mathbf{p}^{* *}$ \\
\hline${ }^{56} \mathrm{Fe}$ & $\begin{array}{c}\mathrm{Y}=20.23 \mathrm{X}+8.071 \\
\mathrm{R}^{2}=0.9961\end{array}$ & $0.896 \pm 0.073$ & $0.961 \pm 0.020$ & 0,210 \\
\hline${ }^{57} \mathrm{Fe}$ & $\begin{array}{c}\mathrm{Y}=0.8172 \mathrm{X}-0.5629 \\
\mathrm{R}^{2}=0.9970\end{array}$ & $1.23 \pm 0.09$ & $0.961 \pm 0.020$ & 0.007 \\
\hline${ }^{55} \mathrm{Mn}$ & $\begin{array}{c}\mathrm{Y}=31.513 \mathrm{X}+4.67 \\
\mathrm{R}^{2}=0.9983\end{array}$ & $2.31 \pm 0.10$ & $2.18 \pm 0.02$ & 0.090 \\
\hline${ }^{64} \mathrm{Zn}$ & $\begin{array}{c}\mathrm{Y}=8180.1 \mathrm{X}+844.8 \\
\mathrm{R}^{2}=0.9993\end{array}$ & $0.306 \pm 0.025$ & $0.284 \pm 0.003$ & 0.200 \\
\hline${ }^{66} \mathrm{Zn}$ & $\begin{array}{c}\mathrm{Y}=2.2652 \mathrm{X}+0.02355 \\
\mathrm{R}^{2}=0.9997\end{array}$ & $0.427 \pm 0.038$ & $0.284 \pm 0.003$ & 0.003 \\
\hline
\end{tabular}

* The values reported are the average and \pm is the mean standard deviation, $\mathrm{n}=3$.

** Statistical parameter, $\mathrm{p}>0.05$ indicates no statistically significant difference at $95 \%$ confidence.

Table 6. Statistical comparison by using ${ }^{83} \mathrm{Kr}^{+}$IFS probe for Fe, Mn and $\mathrm{Zn}$ determinations in wines with high residual sugar by ICP-MS and FAAS. White Moscatel de Alejandría wine with residual sugar 14\% w/v

\begin{tabular}{|c|c|c|c|c|}
\hline & \multicolumn{2}{|c|}{ By ICP-MS IFS ${ }^{83} \mathbf{K r}^{+}$} & \multicolumn{2}{c|}{ By FAAS } \\
\hline Isotope & Linear equation & Concentration found* $\mathbf{m g L}^{-1}$ & Concentration found* mgL ${ }^{-1}$ & $\mathbf{p}^{* *}$ \\
\hline${ }^{56} \mathrm{Fe}$ & $\begin{array}{c}\mathrm{Y}=20.23 \mathrm{X}+408.071 \\
\mathrm{R}^{2}=0.9961\end{array}$ & $0.879 \pm 0.286$ & $1.02 \pm 0.02$ & 0.473 \\
\hline${ }^{57} \mathrm{Fe}$ & $\begin{array}{c}\mathrm{Y}=0.8172 \mathrm{X}-0.05629 \\
\mathrm{R}^{2}=0.9970\end{array}$ & $1.50 \pm 0.32$ & $1.02 \pm 0.02$ & 0.057 \\
\hline${ }^{55} \mathrm{Mn}$ & $\begin{array}{c}\mathrm{Y}=31.513 \mathrm{X}+3.67 \\
\mathrm{R}^{2}=0.9983\end{array}$ & $1.40 \pm 0.19$ & $1.45 \pm 0.01$ & 0.696 \\
\hline${ }^{64} \mathrm{Zn}$ & $\begin{array}{c}\mathrm{Y}=3.7532 \mathrm{X}+0.3585 \\
\mathrm{R}^{2}=0.9998\end{array}$ & $0.260 \pm 0.038$ & $0.294 \pm 0.003$ & 0.200 \\
\hline${ }^{66} \mathrm{Zn}$ & $\begin{array}{c}\mathrm{Y}=2.2652 \mathrm{X}+0.2355 \\
\mathrm{R}^{2}=0.9997\end{array}$ & $0.379 \pm 0.056$ & $0.294 \pm 0.003$ & 0.060 \\
\hline
\end{tabular}

* The values reported are the average and \pm is the mean standard deviation, $\mathrm{n}=3$.

** Statistical parameter, $p>0.05$ indicates no statistically significant difference at $95 \%$ confidence. 
As possible approach regarding the application of different IFS probe, we consider ion isotope ${ }^{13} \mathrm{C}^{+}$as IFS testing probe in a similar manner to ${ }^{56} \mathrm{Fe}^{+}$, ${ }^{55} \mathrm{Mn}^{+},{ }^{64} \mathrm{Zn}^{+}$and ${ }^{66} \mathrm{Zn}^{+}$determination in wine with high and low residual sugar. As has been mentioned above, this study was taken into account because wines with high residual sugar are supply for ${ }^{13} \mathrm{C}^{+}$. This result are show in Table 7. The best results are obtained for $\mathrm{Fe} y \mathrm{Zn}$ determination $(\mathrm{p}>0.05)$ when the ion isotopes ${ }^{56} \mathrm{Fe}^{+}$or ${ }^{57} \mathrm{Fe}^{+}$or ${ }^{64} \mathrm{Zn}^{+}$are used. In consideration to the use of the ion isotope ${ }^{57} \mathrm{Fe}^{+}$(with a low natural abundance, $2.2 \%$ ) the use of ${ }^{13} \mathrm{C}^{+}$in these conditions would able for $\mathrm{Fe}$ analytical determination, however, a low sensitivity is currently obtained for the three elements studied (Table 7, see slope of the calibration curve) when compared respect the used ${ }^{83} \mathrm{Kr}^{+}$or ${ }^{38} \mathrm{Ar}^{+}$ as IFS probes (Tables 5 and 6 ).

Table 7. Statistical comparison by using ${ }^{13} \mathrm{C}^{+}$IFS probe for $\mathrm{Fe}, \mathrm{Mn}$ and $\mathrm{Zn}$ determinations in wines with high residual sugar by ICP-MS and FAAS. White Moscatel de Alejandría wine with residual sugar 14\% w/v.

\begin{tabular}{|c|c|c|c|c|}
\hline \multirow[b]{2}{*}{ Isotope } & \multicolumn{2}{|c|}{ By ICP-MS IFS ${ }^{13} \mathbf{C}^{+}$} & \multicolumn{2}{|c|}{ By FAAS } \\
\hline & Linear equation & $\begin{array}{l}\text { Concentration found } \\
\mathrm{mgL}^{-1}\end{array}$ & $\begin{array}{c}\text { Concentration } \\
\text { found* } \\
\text { mgL }^{-1}\end{array}$ & $\mathbf{p}^{* *}$ \\
\hline${ }^{56} \mathrm{Fe}$ & $\begin{array}{c}\mathrm{Y}=0.0013 \mathrm{X}+0.00057 \\
\mathrm{R}^{2}=0.9837\end{array}$ & $0.221 \pm 0.572$ & $1.02 \pm 0.02$ & 0.080 \\
\hline${ }^{57} \mathrm{Fe}$ & $\begin{array}{c}\mathrm{Y}=8 \times 10^{-5} \mathrm{X}+4 \times 10^{-6} \\
\mathrm{R}^{2}=0.9972\end{array}$ & $1.04 \pm 0.13$ & $1.02 \pm 0.02$ & 0.712 \\
\hline${ }^{55} \mathrm{Mn}$ & $\begin{array}{c}\mathrm{Y}=0.0034 \mathrm{X}+0.00115 \\
\mathrm{R}^{2}=0.9929\end{array}$ & $1.14 \pm 0.08$ & $1.45 \pm 0.01$ & 0.009 \\
\hline${ }^{64} \mathrm{Zn}$ & $\begin{array}{c}\mathrm{Y}=0.0004 \mathrm{X}+0.00008 \\
\mathrm{R}^{2}=0.9987\end{array}$ & $0.300 \pm 0.020$ & $0.294 \pm 0.003$ & 0.634 \\
\hline${ }^{66} \mathrm{Zn}$ & $\begin{array}{c}\mathrm{Y}=0.0002 \mathrm{X}+0.00005 \\
\mathrm{R}^{2}=0.9989\end{array}$ & $0.346 \pm 0.022$ & $0.294 \pm 0.003$ & 0.020 \\
\hline
\end{tabular}

* The values reported are the average and \pm is the mean standard deviation, $\mathrm{n}=3$.

** Statistical parameter, $\mathrm{p}>0.05$ indicates no statistically significant difference at $95 \%$ confidence.

\section{CONCLUSION}

The IFS method by means of ${ }^{38} \mathrm{Ar}^{+},{ }^{83} \mathrm{Kr}^{+}$or ${ }^{13} \mathrm{C}^{+}$as probe in ICP-MS determinations is an effective alternative to reducing isobaric interference in wine samples. The best accuracy for Fe, Mn and $\mathrm{Zn}$ determinations in wines with high and low residual sugar was obtained by using ${ }^{83} \mathrm{Kr}^{+}$as IFS probe. To the best of our knowledge, this is the first time that the IFS method was applied for major metals in wine in a complex matrix sample. This analytical strategy supports the idea that this methodology can be successfully used with other elements, for example these currently found in low concentration $(\mathrm{Cd}, \mathrm{Pb}, \mathrm{Hg}$, As, $\mathrm{Co}, \mathrm{Ni}$, etc). Also, IFS could be widely applied in other types of matrices such as oils, brines, sea water, or biological samples, etc. More studies are currently underway and may provide additional information in order to support for successful implementation of the IFS method.

\section{ACKNOWLEDGEMENTS}

The authors would like to thank the Fondo de Investigación Científica y Tecnológica (FONDECYT) for the research grant (project $\mathrm{N}^{\circ} 1120805$ ). Also the support provided by Group of Applied Instrumental Analysis, Department of Chemistry, Federal University of São Carlos, SP, Brazil.

\section{REFERENCES}

1.- B. Tariba, Biol. Trace Elem Res 144, 143, (2011).

2.- I. Karadjova, B. Izgi, S. Gucer, Spectrochim. Acta Part B 57, 581, (2002).

3.- P. Pohl, Trends in Analytical Chemistry 26, 941, (2007).

4.- G. Grindlay, J. Mora, L. Gras, M.T.C. de Loss-Vollebregt, Anal. Chim. Acta 691, 18, (2011).

5.- M. Waselewska, W. Goessler, M. Zischka, B. Maichin, G. Knapp, J. Anal. At. Spectrom. 17, 1121, (2002).

6.- A. Gonzálvez, S. Armenta, A. Pastor, M. de la Guardia, J. Agric. Food Chem. 56 4943, (2008).

7.- C.M. Almeida, M.T. S.D. Vasconcelos, Anal. Chim. Acta 463, 165, (2002).

8.- S. Wangkarn, S.A. Pergantis, J. Anal. At. Spectrom. 14, 657, (1999).

9.- I. Rodushkin, F. Ödman, J. Food Comp. Anal. 12, 243, (1999).

10.- F.R.S. Bentlin, F.H. Pulgati, V.L. Dressler, D. Pozebon, J. Braz.
Chem. Soc. 22, 327, (2011).

11.- A. Gonzálvez, A. Llorens, M. L. Cervera, S. Armenta, M. de la Guardia, Food Chem. 112, 26, (2009).

12.- H. P. Longerich, B. J. Fryer, D. F. Strong, C. J. Kantipuly, Spectrochim. Acta, Part B 42, 75, (1987).

13.- S. H. Tan, G. Horlick, Appl. Spectrosc. 40, 445 (1986).

14.- E. H. Vanhoe, J. Goosens, L. Moens, D. Richard, J. Anal. At. Spectrom. 9, 177, (1994).

15.- Becker, J. S.; Inorganic Mass Spectrometry: Principles and Application; John Wiley and Sons: Chichester, 2007.

16.- V. L. Dressler, D. Pozebon, A. Matusch, J. S. Becker, Int. J. Mass Spectrom. 266, 25 (2007).

17.- R. Thomas. Practical Guide to ICP-MS: A tutorial for Beginners, $2^{\text {nd }}$ ed., CRC Press, Boca Raton, 2008.

18.- J.Sabine Becker. Inorganic mass spectrometry: Principles and applications $1^{\circ}$ ed., Wiley-interscience, chichester, 2008.

19.- G.L. Donati, R.S. Amais, J.A. Nóbrega, Spectroscopy 27, 44, (2012).

20.- G.L. Donati, R.S. Amais, J.A. Nóbrega, J. Anal. At. Spectrom. 26, 1827, (2011).

21.- R.S. Amais, G.L. Donati, J.A. Nóbrega, Anal. Chim. Acta 706, 223, (2011).

22.- R.S. Amais, G.L. Donati, J.A. Nóbrega, J. Braz. Chem. Soc. 23, 786, (2012).

23.- R.S. Amais, J.A. Nóbrega, G.L. Donati, G, J. Anal. At. Spectrom. 29 , 1258, (2014).

24.- V. Balaram, M. Satyanarananan, D.V. Avdeev, N. Berdnikov, Parijat Roy, S.S. Sawant, K.S.V. Subramanyam, K.V. Anjaiah, C.T. Kamala, Ramavathi Mathur, B. Dasaram, At. Spectrosc. 33, 41, (2012).

25.- Perkin Elmer, Atomic Absorption Spectroscopy: Analytical Methods, $4^{\text {th }}$ ed. USA, 1996.

26.- S.P. Wright, Adjusted P-Values for Simultaneous Inference, Biometrics, 48, 1005, (1992). 